\title{
Efficient transduction of melanoma cells with Sendai viral vectors
}

\section{Melanoma hücrelerinin Sendai viral vektörleri ile verimli transdüksiyonu}

\author{
Açelya YILMAZER-AKTUNA ${ }^{1}$, Hadiseh TAHERI ${ }^{3}$, Alp CAN $^{2}$
}

\begin{abstract}
Objective: Various viral vectors have been developed in order to delivery genes to living cells. Sendai virus (SeV) vectors are important viral vectors due to their properties suitable for gene delivery including transient gene expression, wide host cell specificity, low pathogenicity and strong immunogenicity. SeVs vectorss are highly used in molecular medicine in gene therapy, vaccine technology and regenerative.
\end{abstract}

Methods: It was evaluated the gene delivery efficiency of $\mathrm{SeV}$ particles in various melanoma cell lines by using fluorescence microscope and confocal laser scanning microscope imaging techniques. A375, MDAMB-435, G361 and WM115 cells have been transduced with SeV vectors expressing green fluorescent protein (GFP) at different multiplicity of infections (MOI): 1, 3, and 9. GFP expression was checked at 24 and 48 hours later following transduction. Confocal laser scanning microscopy imaging was calculated to gene delivery efficiency.

Results: It was showed that A375, MDA-MB-435, G361 and WM115 cells are efficiently tranduced by seV even at low virus concentration with fluorescence microscopy imaging. GFP reporter gene activity started to be observed in 24 hours and peaked in 48 hours following viral transduction. Slight toxicity was observed

\section{ÖZET}

Amaç: Yaşayan hücrelere gen salımı yapmak üzere pek çok viral vektör geliștirilmiștir. Sendai viral (SeV) vektörleri geçici gen ifadesi, geniș konak özgüllüğü, düşük patojenite ve yüksek immünojenite gibi özellikleri sayesinde gen aktarımı için önemli vektörlerdir. SeV vektörleri gen tedavisi, așı teknolojileri ve rejeneratif amaçlı moleküler tıpta sıklıkla kullanıır.

Yöntem: Bu çalıșmada, farklı melanoma hücre dizilerinde SeV vektörlerinin gen aktarım verimlilikleri floresan mikroskop ve konfokal lazer taramalı mikroskop görüntüleme teknikleri ile değerlendirilmiștir. A375, MDA- MB- 435, G361 ve WM115 hücreleri yeșil flüoresan proteini (GFP) ifade eden SeV vektörleri tarafından farklı virüs derişimlerinde (enfeksiyon çarpanı (MOI): 1, 3 ve 9) transdükte edilmiștir. GFP ifadesi virüs inkübasyonundan 24 ve 48 saat sonrasında kontrol edilmiștir. Konfokal lazer taramalı mikroskop görüntüleme ile gen salım verimliliği hesaplanmıștır.

Bulgular: Floresan mikroskop görüntüleme ile düșük virüs derișimlerinde dahi (enfeksiyon çarpanı: 1), A375, MDA-MB- 435, G361 ve WM115 hücrelerinin SeV tarafından verimli șekilde transdükte edildiği gösterilmiștir. Viral transdüksiyonu takiben, GFP kontrol gen aktivitesi 24 saat içerisinde gözlemlenmeye bașlanmış ve 48 saatte artıș göstermiștir. Transdüksiyondan 24 saat sonrasında

'Ankara University, Faculty of Engineering, Biomedical Engineering Department, Ankara

${ }^{2}$ Ankara University, School of Medicine, Department of Histology and Embryology, Ankara

${ }^{3}$ Ankara University, Biotechnology Institute, Ankara

İletişim/ Corresponding Author: Açelya YILMAZER - AKTUNA

Ankara University, Biomedical Engineering Department, Gölbaşı, Ankara - Turkey

Tel : +905337787691 E-posta/E-mail : ayilmazer@ankara.edu.tr

Geliş Tarihi / Received : 21.11.2016 Kabul Tarihi/ Accepted : 20.12 .2016

DOI ID : 10.5505/TurkHijyen.2017.98705

Yılmazer-Aktuna A, Taheri H, Can A. Efficient transduction of melanoma cells with Sendai viral vectors.

Turk Hij Den Biyol Derg, 2017; 74(2): 113-120 
following viral transduction in all cell 24 hours later; however, cells recovered and proliferated resulting in efficient gene expression 48 hours later. According to the confocal laser scanning microscopy imaging, more than $80 \%$ of all cell lines expressed GFP 48 hours after viral transduction.

Conclusion: In conclusion, SeV vectors successfully transduced and expressed GFP reporter gene in various melanoma cell lines with high efficiency. This study discovered the use of SeV vectors in melanomaoriginated cells and it can open up wide range of studies involving SeV vectors in cancer therapy and cellular reprogramming fields.

Key Words: Melanoma, Sendai virus particles, GFP, transduction, gene delivery hücrelerde hafif toksisite gözlemlenmiș olsa da 48 saat sonrasında hücreler toksisite etkisinden kurtularak çoğalmıș ve verimli șekilde gen ifadesi göstermișlerdir. Konfokal lazer taramalı mikroskop görüntüleme sonucuna göre 48 saat sonunda tüm hücre dizilerinde hücrelerin \%80'inden fazlası bașarılı bir șekilde GFP genini ifade etmiștir.

Sonuç: Sonuç olarak, SeV vektörleri melanoma hücrelerini yüksek verimlilikle transdükte edip gen ifadesini sağlamıștır. Bu çalıșma SeV vektörlerinin melanoma orijinli hücrelerdeki kullanımını açığa çıkarmış ve SeV vektörlerinin kullanımını içeren kanser tedavi ve hücre programlama alanındaki gelecek çalıșmalarına destek sağlamıștır.

Anahtar Kelimeler: Melanoma, Sendai virüsleri, GFP, transdüksüyon, gen aktarımı

\section{INTRODUCTION}

Sendai virus ( $\mathrm{SeV}$ ) belongs to the Paramyxoviridae family of viruses and it is a respiratory virus of mouse and rat, classified as mouse parainfluenza virus type I. Virus particles are enveloped and $150-250 \mathrm{~nm}$ in diameter. Its genome is a single chain RNA $(15,384$ bases) in the minus sense (1). SeV enters the cells by attaching itself to the sialic acid receptor present on the host cell membrane, therefore it can transduct a variety of cell types (2). The presence of a ubiquitous secondary receptor indispensable for membrane fusion has also been suggested (3). After the activation of fusion protein by a protease, virus and host cell fusion process takes place. This is followed by genome replication and protein synthesis, and finally daughter virus particles are assembled and released to extracellular space. In addition, these vectors rely for their gene expression only on virusencoded RNA polymerase and tubulin, a ubiquitously conserved cytoskeletal protein (4).

Lung/airway epithelium is the main target of
$\mathrm{SeV}$ particles (5), however recombinant SeV vectors can also induce strong transgene expression in cardiovascular system (6), retinal epithelium (7), hepatocytes (8), colon epithelium (9), neurons (2), dendritic cells (10), and in human hematopoietic stem cells (11).

Thanks to their powerful but transient gene expression, wide host cell specificity, low pathogenicity and strong immunogenicity, SeVs are highly used in molecular medicine with different purposes in gene therapy, vaccine technology and regenerative medicine (12-14). Until now, the feasibility for using $\mathrm{SeV}$ particles clinically has been recently applied in the following areas: 1) as a live attenuated vaccine; 2 ) in gene therapy for critical limb ischemia; and 3) in cancer gene therapy (15).

In the present work, we aimed to investigate the gene delivery efficiency of $\mathrm{SeV}$ particles in various melanoma cell lines including A375, MDA-MB-435, 
G361 and WM115. This study examines the use of these vectors in melanocyte-originated cells and it can open up wide range of studies involving $\mathrm{SeV}$ vectors in cancer therapy and cellular reprogramming fields.

\section{MATERIAL and METHOD}

\section{Cell Lines}

Human melanoma cell lines (A375, MDA-MB-435, G361 and WM115) cells were purchased from ATCC (Rockville, MD, USA). A375, MDA-MB-435 and G361 cells were maintained in Dulbecco's Modified Eagle Medium (DMEM, Life Technologies, USA), WM115 maintained in Minimum Essential Medium (MEM, Life Technologies, USA), supplemented with $10 \%$ fetal bovine serum (FBS, Life Technologies, USA), $50 \mathrm{U} /$ $\mathrm{mL}$ penicillin (Life Technologies, USA) , $50 \mu \mathrm{g} / \mathrm{mL}$ streptomycin (Life Technologies, USA), 1\% L-glutamine (Life Technologies, USA) and 1\% non-essential amino acids (Life Technologies, USA) at $37^{\circ} \mathrm{C}$ in a humidified atmosphere of $5 \% \mathrm{CO}$.

\section{Sendai Virus Transductions}

A375, MDA-MB-435, G361 and WM115 melanoma cells were plated into a 24-well culture plate at a density of $1 \times 104$ cells per well and incubated at $37^{\circ} \mathrm{C}$, $5 \% \mathrm{CO}$, overnight. SeV vectors (CytoTuneEmGFP Sendai Fluorescence Reporter, Thermo Fisher Scientific) expressing emerald green fluorescent protein (EmGFP) were added at different multiplicity of infections (MOI): 1, 3, and 9. After 24 hours of incubation period, transduction medium was removed and cells were washed with PBS (Life Technologies, USA). Fresh complete medium was added and plates were returned to the incubator. GFP expression was analyzed via confocal laser scanning microscopy (CLSM) and fluorescence microscopy.

\section{CLSM Imaging}

Reporter gene activity was assessed in cells transduced at $\mathrm{MOI} 9$ concentration at 24 and $48 \mathrm{~h}$ of culture. Healthy cells on 24-well plates were observed under CSLM, (Zeiss LSM 510 Meta laser scanning confocal microscope, Germany), equipped with a $30 \mathrm{~mW}$ argon, a $1 \mathrm{~mW}, 543 \mathrm{~nm}$ HeNe, and a $5 \mathrm{~mW}$, $633 \mathrm{~nm}$ HeNe laser lines. Samples were analyzed to obtain a DIC image combined with a GFP fluorescence image. Representative images were taken at $40 \mathrm{x}$ magnification.

\section{Fluorescence Microscopy}

At 48 hours of culture, cells were washed with PBS buffer and fixed with $4 \%$ formaldehyde. Samples were imaged under fluorescence microscope (EVOS FL, Thermo Fisher Scientific) in order to determine the optimum MOI concentration. Representative images were obtained using two channels (DIC-phase contrast and GFP channels) at $20 \times$ magnification.

\section{Image Analysis}

The number of GFP positive and negative cells was analyzed in five different regions of a well ( 3 wells per condition and time point) by using ImageJ 1.48 software. The percentage of GFP positive cells were plotted for each condition.

\section{RESULTS}

In an attempt to determine the gene delivery efficiencies of $\mathrm{SeV}$ vectros in melanoma cells, various cell lines of melanoma origin were transduced with $\mathrm{SeV}$ particles at different $\mathrm{MOI}$ concentrations. GFP expression was used in order to assess the reporter gene activity. Fluorescence microscopy imaging of GFP expressing cells demonstrated that all cell lines were shown to be transduced by SeV particles at 48 hour time point (Figure 1). The fluorescent signals were both detected in nuclear and cytoplasmic regions. Furthermore, increasing the $\mathrm{MOI}$ concentration increased the number of cells transduced after viral incubations, as expected. Therefore, according to findings illustrated in Figure 1, we assumed that SeV vectors can be used in all studied cell lines, preferably between MOI 3 and 9 . 

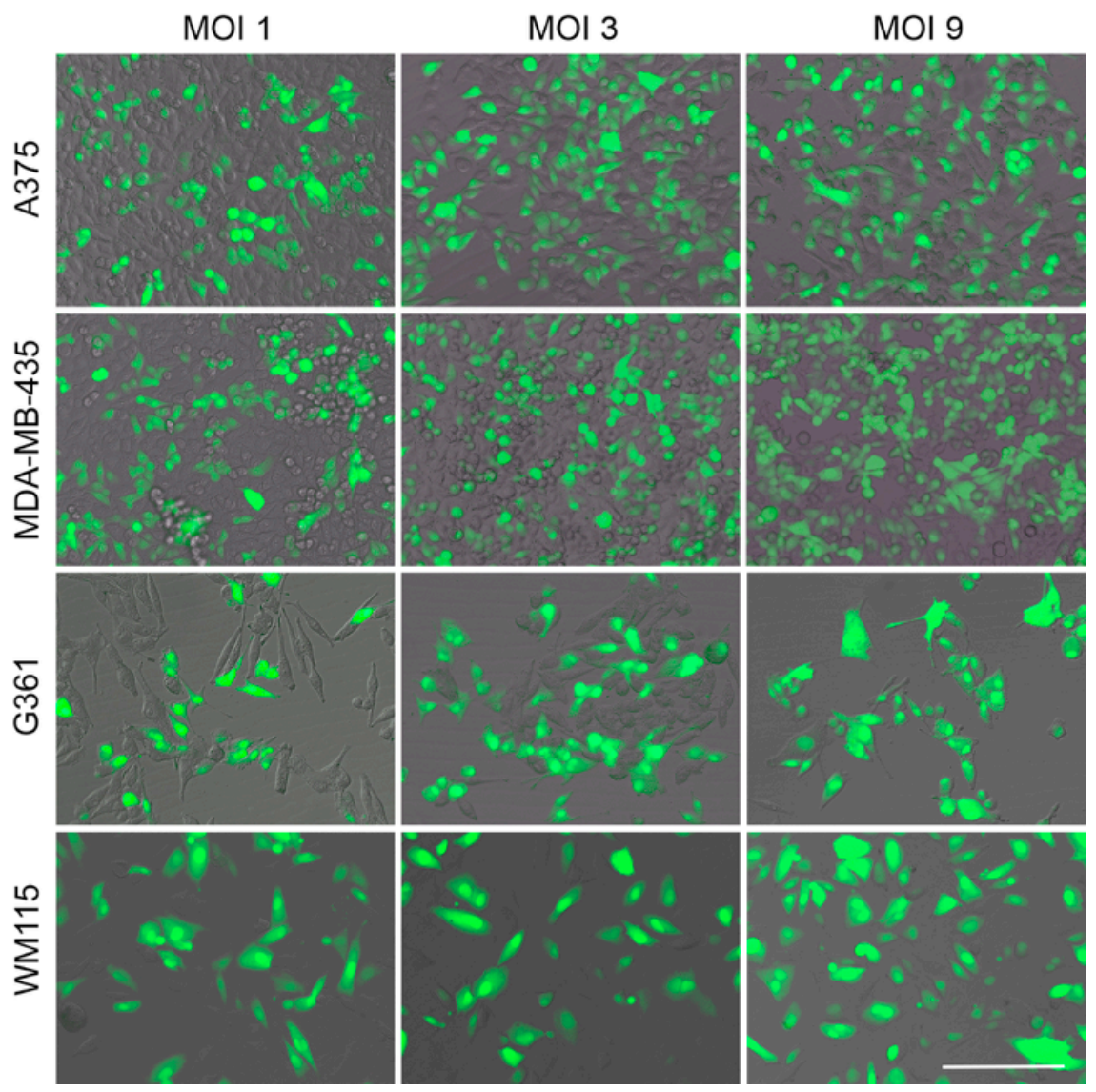

Figure 1. SeV transductions of different melanoma cell lines at different $\mathrm{MOI}$ concentrations. A375, MDA-MB-435, G361 and WM115 cell lines were transduced with SeV vectors expressing GFP (MOI: 1, 3 and 9) for $24 \mathrm{~h}$ in complete media. GFP expression (green signal) was observed after $48 \mathrm{~h}$ under fluorescence microscopy. Scale bar $=400 \mu \mathrm{m}$

Transgenes carried via SeV vectors are not inserted into the host genome as in the case of lentiviral or retroviral vectors; therefore transgene expression profiles should be carefully studied. Fluorescence over 48 hour time interval was then evaluated by CLSM in order to determine the kinetics of gene expression. As shown in Figure 2, in all cell lines at MOI 9, GFP expression started as early as 24 hours and increased further at 48 hours (Figure 2). Cells observed at 48 hours showed the highest amount of fluorescence; therefore we concluded that GFP expression peaks around 48 hours following viral transduction, after which the mRNA and protein levels were started to decrease within the cells.
In order to determine whether any difference is concerned between the transduction efficiencies; the number of GFP-positive cells were analyzed by Image J. As shown in Figure 3, at 24 hours, transduction efficiency was around $40 \%$ for the A375 cells, whereas higher efficiencies were noted in other cell lines showing $60 \%, 70 \%$ and $80 \%$ expression efficiency in MDA-MB-435, WM115 and G361 cells, respectively (Figure 3). Furthermore, the transduction efficiency showed higher degree of variation throughout plates at $24 \mathrm{~h}$ time point, however after $48 \mathrm{~h}$, there were more homogenous distribution of GFP-positive cells in all cell lines. After $48 \mathrm{~h}$, more than $80 \%$ of all cell lines expressed GFP when analyzed by CLSM. 


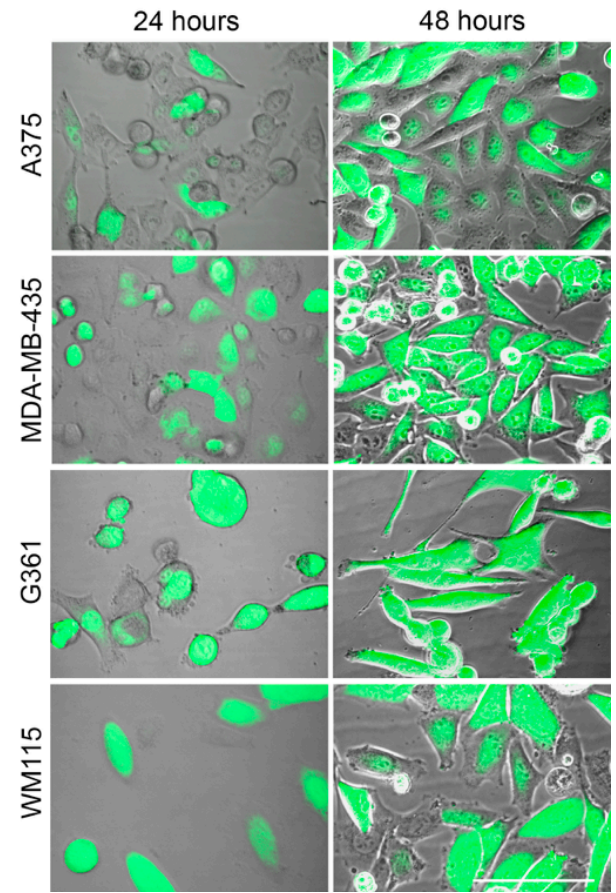

Figure 2. GFP expression over time following SeV transductions. A375, MDA-MB-435, G361 and WM115 cells were transduced with SeV vectors expressing GFP (MOI:9). GFP expression was observed by CLSM at 24 and $48 \mathrm{~h}$. Scale bar $=100 \mu \mathrm{m}$

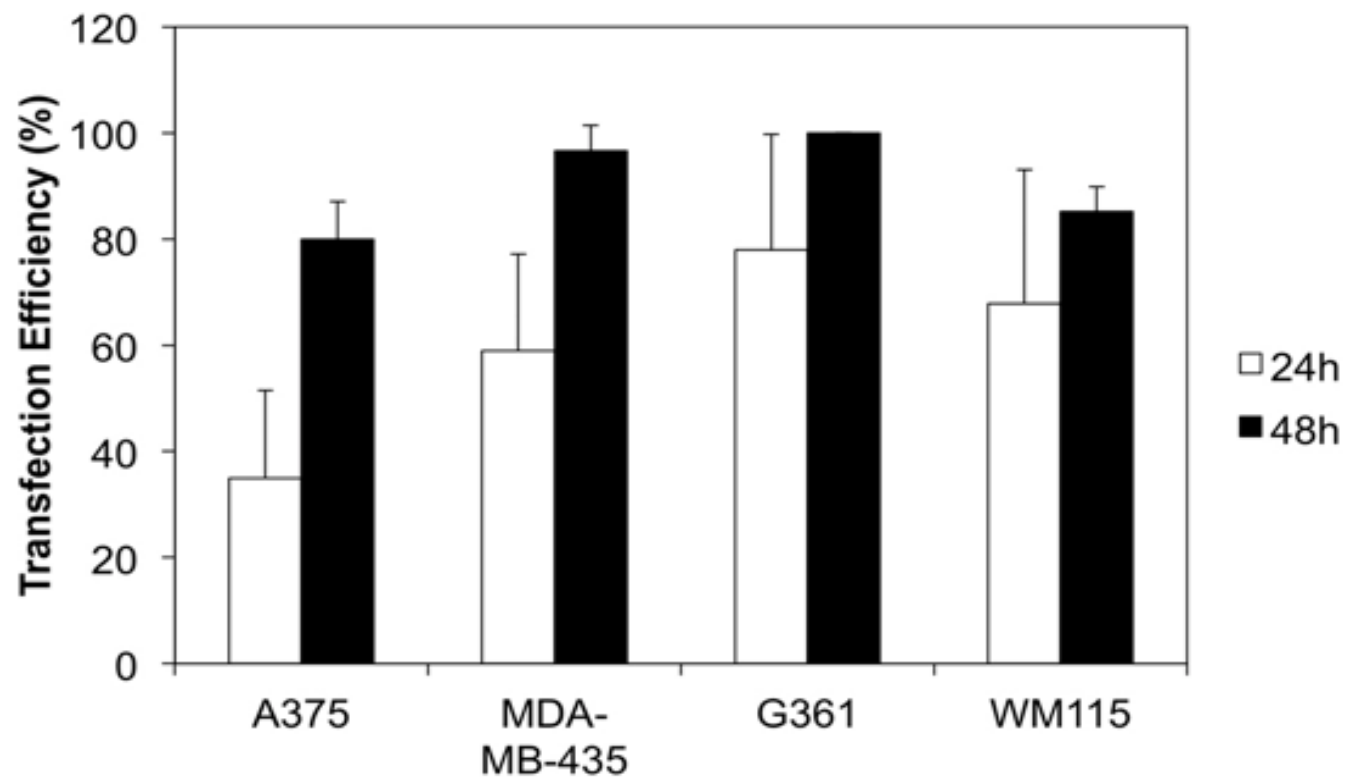

Figure 2. SeV transduction efficiencies in melanoma cell lines. A375, MDA-MB-435, G361 and WM115 cells were transduced with SeV vectors expressing GFP (MOI:9). GFP expression was imaged by CLSM and then quantified using Image J. Percentage of transduction efficiencies for all cell lines were plotted 
We also observed slight toxicity at $24 \mathrm{~h}$ following viral transductions in all cell lines, as evident by the presence of round GFP-positive cells. As discussed by Oishi et al., this is an indication of higher degree of viral uptake (16). However, by $48 \mathrm{~h}$, cells recovered and proliferated resulting in efficient gene delivery via SeV vectors.

\section{DISCUSSION}

In this study, SeV vectors successfully transduced and expressed GFP reporter gene in various melanoma cell lines with high efficiency. These results suggest that this vector has great potential for use in gene delivery and cellular reprogramming studies in cancer. For example, one of the areas where these vectors can be applied effectively is cancer cell reprogramming. In cellular reprogramming, induced pluripotent stem (iPS) cells are generated by a forced expression of reprogramming transcription factors (17). Currently, it is achieved mostly by using classical retro/lentivirusbased vectors. Unfortunately, low reprogramming efficiency and chromosomal integration of exogenous reprogramming factors limit the translation of these viral vectors into clinical settings (18). Thanks to their safer nature, SeV vectors can overcome these limitations. Until now, SeV vectors have been already used to generate iPS cells from somatic cells involving fibroblasts (19), peripheral blood mononuclear cells (20), T and B cells (21), mesenchymal stem cells (22). These studies showed that integration free iPS cells can be obtained fast and efficiently from a variety of cell types. With the help of SeV vectors, cellular reprogramming of cancer cells may also provide a powerful tool to better understand both regenerative and cancer-fate processes, with a potential to develop novel therapeutic approaches or disease modeling (23).

In conclision, we demonstrated that exogenous genes carried by $\mathrm{SeV}$ vectors can be efficiently expressed in various melanoma cell lines, even at low MOI concentrations. The reporter gene expression could be detected as early as 24 hours following transduction. Therefore the SeV vectors are important candidates for gene transfer to melanoma cells due to its potential for superior and safer gene delivery.

\section{ACKNOWLEDGMENTS}

Authors acknowledge support by the Scientific and Technological Research Council of Turkey (TUBITAK, grant number 113S897). Authors confirm that there are no known conflicts of interest associated with this publication. 


\section{REFERENCES}

1. Lamb RA, Kolakofsky D. Paramyxoviridae: The Viruses and Their Replication In: D. M. Knipe, P. M. Howley, D. E. Griffin, R. A. Lamb, M. A. Martin, B. Roizman, and S. E. Straus (eds.), Fields virology, 4th ed., Philadelphia, Lippincott Williams \& Wilkins, 2001:1305-40

2. Li H-O, Zhu Y-F, Asakawa M, Kuma H, Hirata T, Ueda Y, et al. A Cytoplasmic RNA Vector Derived from Nontransmissible Sendai Virus with Efficient Gene Transfer and Expression. J Virology, 2000;74(14):6564-9.

3. Eguchi A, Kondoh T, Kosaka H, Suzuki T, Momota H, Masago A, et al. Identification and Characterization of Cell Lines with a Defect in a Post-adsorption Stage of Sendai Virus-mediated Membrane Fusion. J Biol Chem, 2000;275(23):17549-55.

4. Bitzer M, Armeanu S, Lauer UM, Neubert WJ. Sendai virus vectors as an emerging negative-strand RNA viral vector system. J Gene Med, 2003;5(7):543-53.

5. Yonemitsu Y, Kitson C, Ferrari S, Farley R, Griesenbach U, Judd D, et al. Efficient gene transfer to airway epithelium using recombinant Sendai virus. Nat Biotech. 2000;18(9):970-3.

6. Masaki I, Yonemitsu Y, Komori K, Ueno H, Nakashima $Y$, Nakagawa K, et al. Recombinant Sendai virusmediated gene transfer to vasculature: a new class of efficient gene transfer vector to the vascular system. FASEB J, 2001;15(7)1294-6.

7. Murakami Y, Ikeda Y, Yonemitsu Y, Tanaka S, Kondo $\mathrm{H}$, Okano S, et al. Newly-developed Sendai virus vector for retinal gene transfer: reduction of innate immune response via deletion of all enveloperelated genes. J Gene Med, 2008;10(2):165-76.

8. Fujita S, Eguchi A, Okabe J, Harada A, Sasaki K, Ogiwara N, et al. Sendai Virus-Mediated Gene Delivery into Hepatocytes via Isolated Hepatic Perfusion. Biol Pharm Bull, 2006;29(8):1728-34.

9. Goto T, Morishita M, Nishimura K, Nakanishi M, Kato A, Ehara J, et al. Novel Mucosal Insulin Delivery Systems Based on Fusogenic Liposomes. Pharmaceut Res, 2006;23(2):384-91.
10. Shibata S, Okano S, Yonemitsu Y, Onimaru M, Sata S, Nagata-Takeshita $\mathrm{H}$, et al. Induction of Efficient Antitumor Immunity Using Dendritic Cells Activated by Recombinant Sendai Virus and Its Modulation by Exogenous IFN-B Gene. J Immunol, 2006;177(6):3564-76.

11. Nishimura $K$, Sano $M$, Ohtaka $M$, Furuta $B$, Umemura Y, Nakajima Y, et al. Development of Defective and Persistent Sendai Virus Vector: A unique gene delivery/expression system ideal for cell reprogramming. J Biol Chem, 2011;286(6):4760-71.

12. Mochiduki Y, Okita K. Methods for iPS cell generation for basic research and clinical applications. Biotechnol J, 2012;7(6):789-97.

13. Saga K, Kaneda Y. Virosome Presents Multimodel Cancer Therapy without Viral Replication. Biomed Res Int, 2013;2013:764706.

14. dUra T, Okuda K, Shimada M. Developments in Viral Vector-Based Vaccines. Vaccines, 2014;2(3):624.

15. Mahito N, Makoto O. Development of Sendai Virus Vectors and their Potential Applications in Gene Therapy and Regenerative Medicine. Curr Gene Ther, 2012;12(5):410-6.

16. Oishi K, Noguchi H, Yukawa H, Inoue M, Takagi S, Iwata $\mathrm{H}$, et al. Recombinant Sendai Virus-Mediated Gene Transfer to Mouse Pancreatic Stem Cells. Cell Transplant, 2009;18(5):573-80

17. Takahashi K, Yamanaka S. Induction of Pluripotent Stem Cells from Mouse Embryonic and Adult Fibroblast Cultures by Defined Factors. Cell, 2006;126(4):663-76.

18. de Lázaro I, Yilmazer A, Kostarelos K. Induced pluripotent stem (iPS) cells: Anew source for cell-based therapeutics? J Control Release, 2014;185:37-44.

19. Choi J, Lee S, Mallard W, Clement K, Tagliazucchi GM, Lim $\mathrm{H}$, et al. A comparison of genetically matched cell lines reveals the equivalence of human $\mathrm{PPSC}$ and ESCs. Nat Biotech, 2015;33(11):1173-81. 
20. Zhang X-B. Cellular Reprogramming of Human Peripheral Blood Cells. Genomics Proteomics Bioinformatics, 2013;11(5):264-74

21. Bueno C, Sardina JL, Di Stefano B, Romero-Moya D, Munoz-Lopez A, Ariza L, et al. Reprogramming human $B$ cells into induced pluripotent stem cells and its enhancement by C/EBP[alpha]. Leukemia, 2015;30(3):674-82.

22. Miere C, Devito L, Ilic D. Sendai Virus-Based Reprogramming of Mesenchymal Stromal/Stem Cells from Umbilical Cord Wharton's Jelly into Induced Pluripotent Stem Cells. In: Turksen K, Nagy A, editors. Induced Pluripotent Stem (iPS) Cells. Methods in Molecular Biology. 1357: Springer New York; 2016:3344
23. Yilmazer A, de Lázaro I, Taheri H. Reprogramming cancer cells: A novel approach for cancer therapy or a tool for disease-modeling? Cancer Lett, 2015;369(1):1-8. 